\title{
Pazarlamada Yeni Bir Çerçeve: Sosyal Medya ve Web 2.0
}

\author{
A New Framework In Marketing: Social Media And Web 2.0
}

\section{Yasemin GEDIKK}

Dr., Beykent Üniversitesi, SBE, İşletme Yönetimi A.B.D., dr.yasemingedik@hotmail.com https://orcid.org/0000-0002-1166-3227
Makale Başvuru Tarihi: 19.03.2020

Makale Kabul Tarihi: 10.05 .2020

Makale Türü: Araştırma Makalesi

\begin{abstract}
Anahtar
Kelimeler:

Sosyal Medya,

Web 2.0,

Sosyal Medya

Platformlarl,

Sosyal Medya

Pazarlama

Stratejileri,
\end{abstract}

Keywords:

Social Media,

Web 2.0,

Social Media

Platforms,

Social Media

Marketing

Strategies,

\section{ÖZET}

İnternet ve teknolojinin olağanüstü hızda ilerleyişi, sürekli olarak yeni fikirlerin gerçekleşmesi için yeni firsatlar sunarak işletmelerin pazarlama yaklaşımlarında da köklü değişimleri beraberinde getirmişsir. Bloglar, sosyal medya platformlarl, Web 2.0, sosyal ağlar gibi yeni nesil çevrimiçi konseptler giderek daha fazla kullanıcının dikkatini çekmeye başlamıştır. Sosyal medya, işletmelerin müşteriyle /toplumla etkileşime girme ve hizmetlerini sunma şeklini değiştirerek anahtar faktör haline gelmeye başlamıştır. Daha önce işletmelerin, sosyal medyayı neden kullanmaları gerektiğiyle ilgili sorular, yerini sosyal medyayı nasıl kullanmaları gerektiği ile ilgili sorulara bırakmıştır. Sosyal medya, işletmelerin sadece hedef kitleleriyle yakından iletiş̧im kurmasını sağlamakla kalmaz, marka farkındalığ ve satışlarını arttırmak için de ideal bir ortam sunar. Işsletmelerin, rekabette öne geçmek için her biri kendi içinde farkl nitelikler ve fonksiyonlar sunan sosyal medya platformlarından uygun olanı seçmesi de bir diğer önemli noktadır. Bu makalenin amacl, sosyal medya, sosyal medya pazarlamast, sosyal medyanin avantajlarl, Web 2.0, sosyal medya stratejileri ve sosyal medya platformalar hakkında geniş bir kavramsal çerçeve oluştururken, konuyla ilgili güncel istatistikleri de paylaşmaktır. Ayrıca, sözkonusu faaliyetleri geliştirirken yöneticilerin karar vermelerine rehberlik edecek detaylı bir teorik bakış açısı sunmaktadır.

\section{ABSTRACT}

Extraordinary advances in the internet and technology have brought radical changes in the marketing approaches of businesses, by constantly offering new opportunities for new ideas to come true. Next generation online concepts such as blogs, social media platforms, Web 2.0, social networks are getting more and more users' attention. Social media has begun to become a key factor by changing the way businesses interact with customers / society and deliver their services. Previously, the questions about why businesses should use social media left their place to the questions about how to use social media. Social media not only enables businesses to communicate closely with their target audiences, but also provides an ideal environment to increase brand awareness and sales. Another important point is that businesses choose the appropriate one from social media platforms, each offering different qualities and functions in order to take the lead in competition.The purpose of this article is to provide a broad conceptual framework on social media, social media marketing, social media advantages, Web 2.0, social media strategies and social media platforms, while also sharing up-to-date statistics on the subject. It also provides a detailed theoretical perspective to guide managers in making decisions while developing these activities. 


\section{GIRİŞ}

Hızla gelişen teknolojinin dünyayı ve günlük faaliyetleri yeniden şekillendirmesiyle işletmeler televizyon, gazete, dergi gibi geleneksel iletişim biçimlerinin ötesine geçmekte ve giderek daha yeni iletişim biçimlerini benimsemektedir. Bu gelişimi desteklemede internet önemli bir unsurdur (Irshad ve Ahmad, 2019:1-2; Alalwan vd., 2017:4; Soegoto ve Utomo, 2019:1). İnsan etkileşimindeki en büyük değişikliklerden biri, son zamanlarda çevrimiçi sosyal ağların yaygınlaşmasıdır. Çevrimiçi sosyal davranışı kolaylaştıran web tabanlı platformların hızlı büyümesi, insan faaliyetlerinin, habitatların ve etkileşimlerin doğasını önemli derecede farklılaştırmıştır. (Tiago ve Verissimo, 2014:703). Sosyal medya araçlarının yükselişi, bireylerin belirli bir şirket veya kuruluşla ilgili olumlu ve olumsuz deneyimlerini dünyayla paylaşmalarını sağlamıştır (Cox ve McLeod, 2014:851).

Sosyal medya, sohbet ortamını kullanarak bilgi, bilgi ve görüş paylaşmak için çevrimiçi toplanan insanlar arasındaki etkinlikler, uygulamalar ve davranışlardır. Sosyal medya olgusunun ortaya çıkması, pazarlamada geleneksel yöntemlerden sosyal medya platformlarının kullanımına doğru bir kayma yaratmıştır (Quy vd., 2019:62). Günümüzde World Wide Web, mobil uygulamalar, sosyal medya ve diğer dijital iletişim teknolojilerinin kullanımı milyarlarca insanın günlük hayatının bir parçası haline gelmiştir. Sosyal ağlar, çevrimiçi kullanıcıların vakit geçirmesinin, çevreleriyle iletişimde kalmasının, haberleri ve diğer içerikleri takip etmesinin en popüler yollarından biridir. İnsanlar sosyal medyayı, ürünler hakkında bilgi almak, ürünleri satın almak, başkalarıyla iletişim kurmak ve satın alma deneyimlerini iletmek için kullanmaktadır. Bu durum, sosyal medyanın, tüketici davranışını etkileyen faktörler arasında ilk sıralara çıkarmaktadır (Theocharidis vd., 2019:375-376).

Sosyal medya, belirli bir içeriğin, yani fotoğrafların, videoların, fikirlerin ve yorumların paylaşılmasını içeren iki yönlü bir iletişim sağlayan Web 2.0 ve web tabanlı uygulamalardan oluşur. Sosyal medya sayesinde kullanıcılar, duygularını, deneyimlerini, düşüncelerini ve açıklamalarını paylaşabilirler (Mazurek vd., 2019:118). 2005 yılında geniş bir popülerlik kazanan terim, genellikle son kullanıcılar tarafından halka açık olarak oluşturulan ve kullanılan çeşitli medya içeriği biçimlerini tanımlamaktadır. Ekonomik İşbirliği ve Kalkınma Örgütü'ne (OECD) göre, kullanıcı tarafından oluşturulan içeriğin bu şekilde değerlendirilebilmesi için üç temel gereksinimi yerine getirmesi gerekmektedir: ilk olarak, herkesin erişebileceği bir web sitesinde veya seçilen bir grup insanın erişebileceği bir sosyal ağ sitesinde yayınlanması; ikincisi, belirli miktarda yaratıcı çaba göstermesi ve üçüncüsü, profesyonel rutinlerin ve uygulamaların dışında yaratılmış olması gerekir (Kaplan ve Haenlein, 2010:61).

Sosyal medya, bilgi edinmekten satın alma sonrası memnuniyetsizlik bildirimlerine kadar tüketici davranışlarını da etkilemiştir. Sosyal medyanın, işletmelerin tüketicilerle zamanında ve düşük maliyetlerle ilişkilerini geliştirmesine yardımcı olmak, tüketicilerin alg1 ve tutumlarını etkilemek, satışları arttırmak, daha önce ulaşılamayan müşterilere ulaşılmasını sağlamak, benzer düşüncedeki insanları bir araya getirmek gibi birçok avantaj1 bulunmaktadır (Vinerean vd., 2013:67; Tsimonis ve Dimitriadis, 2014:331-332). We Are Social 2020 Ocak raporuna göre, Türkiye'deki 16-64 yaş arası kullanıcılar günde ortalama 7 saat 29 dakika internet kullanmaktadır. Aynı yaş aralığının mobil internet kullanımı ise günde ortalama 4 saat, sosyal medya kullanımı ise günde ortalama 2 saat 55 dakikadır. Türkiye'de iş amacıyla sosyal medya kullananların oranı yüzde 44'tür. Kişi başına düşen sosyal medya hesabı dünyada ortalama 8,6 iken, Türkiye'de 9,1'dir. Türkiye'de Facebook reklamlarının erişim oranının yüzde 58, Instagram reklam erişim oranı ise yüzde 57'dir. 8 milyon 400 bin erişim hacmi ile Tükiye, LinkedIn reklamı erişiminde en yüksek potansiyele sahip ülkeler arasında 15. sırada yer alıyor. Türkiye, Twitter reklamı erişiminde en yüksek potansiyele sahip ülkeler arasında 5. sırada yer almaktadır (https://wearesocial.com/, E.T.: 01.01.2020).

Geçtiğimiz 40 yıl boyunca, işletmelerin işlerini nasıl yürüttügü ve insanların nasıl işbirliği yaptığı konusunda büyük değişimler yaşanmıştır. Dünya çapında sosyal ağlardaki kullanıcı sayısındaki yüksek artış ve son birkaç yıl içinde küresel ticaret çevrelerinde sosyal medya kullanımının yaygınlığına dayanarak, insanların sosyal medyayı günlük yaşamlarına hızla adapte ettiğini söylemek mümkündür. Bu yüzden araştırmacılar, sosyal medya pazarlamasına yoğun ilgi göstermektedir. Önceki araştırmalar; kullanıcı tarafından oluşturulan içerik, müşteri katılımı, işletme tarafından oluşturulan içerik, sosyal medya sayfalarında işletmelerin pazarlama iletişimi, çevrimiçi ağızdan-ağıza pazarlama ve çevrimiçi marka toplulukları gibi sosyal medya pazarlamasının çeşitli yönlerini (Pan vd., 2019:73-74; Leung vd., 2015:148) incelemiştir. Ayrıca sosyal medya pazarlamasının tüketici davranışı üzerindeki etkilerini ele almıştır. Bu çalışmalar, sosyal medyanın pazarlama özelliklerinden veya sosyal ağ etkisi/ algılanan sosyal medya içerik deneyimi gibi sosyal medya özelliklerinden gelen sosyal 
medyanın pazarlama sonuçları üzerindeki (müşteri davranışı açısından) etkisini açıklamaktadır (Ananda vd., 2014:2).

Dünyada internet kullanan insan sayısı Ocak 2019'a göre \%7 artışla (298 milyon yeni kullanıc1) 4.54 milyara yükselmiştir. Ocak 2020'de itibariyle, 3.80 milyar sosyal medya kullanıcısı bulunmakta ve bu sayı 2019'dan bu yana \%9 (321 milyon yeni kullanıcı) artmıştır. Ortalama bir internet kullanıcısı her gün çevrimiçi olarak 6 saat 43 dakika geçirmektedir. Günlük uyku saatinin ortalama 8 saat olduğu düşünülürse, uyanık olunan zamanın \%40'ından fazlasını internete ayrılmaktadır. Global Web Index, kişi başına sosyal medya kullanımının günlük ortalama 2 saat 24 dakika olduğunu bildirmektedir. Ayrıca Dünyadaki internet kullanıcılarının yüzde 92'si şu anda mobil cihazlar üzerinden bağlanmaktadır (https://wearesocial.com/, E.T.: 01.01.2020).

Bu makalenin amacı, sosyal medya, sosyal medya pazarlaması, sosyal medyanın avantajları, Web 2.0, sosyal medya stratejileri ve sosyal medya platformaları hakkında geniş bir kavramsal çerçeve oluştururken, konuyla ilgili güncel istatistikleri de paylaşmaktır. Ayrıca, sözkonusu faaliyetleri geliştirirken yöneticilerin karar vermelerine rehberlik edecek detaylı bir teorik bakış açısı sunmaktadır.

\section{SOSYAL MEDYA}

Sosyal medya terimi, teknik beceri gerektirmeden, içeriğin kullanıcılar tarafindan kolayca oluşturulmasını, iyileştirilmesini ve paylaşılmasını kolaylaştırmak için Web 2.0 teknolojilerinden yararlanan çevrimiçi platformlar ve mobil uygulamalar ailesini açıklar. Sosyal medya başlangıçta büyük ölçüde metin tabanıyken, ses, görsel ve animasyonlu içeriği kapsayacak şekilde hızla gelişmiştir. Özellikle son yıllarda, daha fazla görsel ve canlı içeriğe doğru kayda değer bir geçiş olmuş ve kısa video hikayeler çeşitli platformlarda popüler hale gelmiştir. Genel olarak, sosyal medya ortamı son derece dinamiktir, düzenli olarak yeni özellikler ve uygulamalar ortaya çıkmakta ve diğerleri kaybolmaktadır (Gretzel, 2019:1). Sosyal medya, endüstri devriminden bu yana gerçekleşen en büyük devrim olarak kabul edilmektedir (Ansari vd., 2019:5).

Sosyal medya, Web 2.0'ın teknolojik ve ideolojik temelleri üzerine inşa eden ve kullanıcı tarafından üretilen içeriğin oluşturulmasına ve değiştirilmesine izin veren bir grup internet tabanlı uygulama olarak tanımlanmaktadır. Web 2.0, teknolojik ve ideolojik temeli temsil ettiğinde, kullanıcı tarafından oluşturulan içerik, insanların sosyal medyayı kullandıkları tüm yolların toplamı olarak görülebilir (Kaplan ve Haenlein, 2010:61). Sosyal medya, kullanıcı tarafından paylaşılabilecek içerik oluşturan yazılım araçlarını tanımlayan geniş bir terimdir (Paquette, 2013:3). Sosyal medya, etkileşimleri, işbirliklerini ve içerik paylaşımını kolaylaştırmayı amaçlayan çevrimiçi uygulamalar, platformlar ve medyadır (Kim ve Ko, 2012:1481). Sosyal medya, teknolojinin entegrasyonu, sosyalleşme, düşüncelerin kelimeler veya görsel materyaller yoluyla paylaşılmasıdır (Ansari vd., 2019:5). Sosyal medyanın temel tanımlarının bir özeti Tablo l'de verilmektedir.

Tablo 1. Sosyal Medyanın Temel Tanımları

\begin{tabular}{|c|c|}
\hline Yazar(lar) & Tanım \\
\hline Blackshaw ve Nazzaro (2004) & $\begin{array}{l}\text { Sosyal medya, ortak ilgi alanları hakkında başkalarıyla bilgi paylaşmak isteyen tüketiciler tarafından oluşturulan ve } \\
\text { kullanılan çeşitli yeni çevrimiçi bilgi kaynaklarını temsil eder. }\end{array}$ \\
\hline Richeter ve Koch (2007) & $\begin{array}{l}\text { Sosyal medya, kullanıcılar arasında etkileşimi, işbirliğini ve paylaşımı kolaylaştıran her türlü çevrimiçi medya ve } \\
\text { içerik uygulaması veya platformudur }\end{array}$ \\
\hline Russo vd. (2008) & $\begin{array}{l}\text { Sosyal medya uygulamaları, katılımcı bir kültürel deneyimi ve kurumlar arasında çevrimiçi işbirliğini kolaylaştırma } \\
\text { işlevine sahiptir }\end{array}$ \\
\hline Kaplan ve Haenlein (2010) & $\begin{array}{l}\text { Sosyal medya, Web } 2.0 \text { 'ın ideolojik ve teknolojik temelleri üzerine inşa edilmiş, kullanıcı tarafindan üretilen } \\
\text { içeriklerin oluşturulmasına ve değiştririlmesine izin veren bir grup İnternet tabanlı uygulamadır }\end{array}$ \\
\hline Xiang ve Gretzel (2010) & Sosyal medya internette tüketici tarafindan üretilen içeriği taşıyan ilk araç olarak düşünülmüsşür \\
\hline Kietzmann vd. (2011) & $\begin{array}{l}\text { Sosyal medya, bireylerin ve toplulukların kullanıcı tarafindan oluşturulan içeriği paylaştı̆̆ı, birlikte oluşturduğu, } \\
\text { tartıştı̆ı ve değiştirdiği mobil teknolojileri ve web tabanlı son derece etkileşimli platformlardır. }\end{array}$ \\
\hline Lim vd. (2012) & $\begin{array}{l}\text { Sosyal medya, hedef markanın kimliğinin veya imajının gelisstirilmesinde işbirliği yapan tüketicilerle iki yönlü } \\
\text { görüşmelere olanak tanır ve uygulamalar gönderme, etiketleme gibi tipik internet etkinliklerine atıfta bulunur. }\end{array}$ \\
\hline De Vries vd. (2012) & $\begin{array}{l}\text { Sosyal medya, müşsteri ilişsilerini geliştiren iletişim araçlarıdır ve müşteri ilişkileri, pazarlama iletişimini ve } \\
\text { markalaşmayı yönetmek için kullanılabilir. }\end{array}$ \\
\hline
\end{tabular}




\begin{tabular}{|c|c|}
\hline Leonardi vd. (2013) & Sosyal medya, kurum içindeki iç iletişim ve sosyal etkileşim için araçlardır. \\
\hline Rapp vd. (2013) & $\begin{array}{l}\text { Sosyal medya, şirketlerin ve müşterilerin ağdaki marka ve ürünler hakkında bilgi ve içerik paylaşabilecekleri } \\
\text { etkileşimli platformlardır }\end{array}$ \\
\hline Zembik (2014) & Sosyal medya, öncelikli fikri sosyal etkileşimi sağlamak olan İnternet ve mobil uygulamalardır \\
\hline Filo vd. (2015) & $\begin{array}{l}\text { Sosyal medya, kullanıcılar tarafindan oluşturulan içeriğin kuruluşlar ve bireyler arasında etkileşimini, birlikte } \\
\text { oluşturulmasını, geliştirilmesini ve paylaşılmasını kolaylaştıran yeni multimedya teknolojileridir }\end{array}$ \\
\hline Godey vd. (2016) & $\begin{array}{l}\text { Sosyal medya, sosyal topluluklarında tüketicilerle daha fazla kişisel ilişki kurmak ve oluşturmak için büyük firsatlar } \\
\text { sunar ve marka içeriğinin oluşturulma, dağıtılma ve tüketilme şeklini değiştirir }\end{array}$ \\
\hline Kumar vd. (2017) & $\begin{array}{l}\text { Sosyal medya, şirketlerin birbirleriyle ve şirketle etkileşime girebilecek müşterileri çekme ve elde tutma şeklini } \\
\text { değiştirir }\end{array}$ \\
\hline Alalwan (2018) & $\begin{array}{l}\text { Sosyal medya, pazarlama ve reklamcılık faaliyetleri için giderek daha fazla kullanılan platformlardır ve insanların, } \\
\text { kuruluşların ve hatta hükümetlerin ticari, sosyal, politik ve eğitim düzeyinde etkileşim kurdukları yeri temsil } \\
\text { etmektedir. }\end{array}$ \\
\hline Kapoor vd. (2018) & $\begin{array}{l}\text { Sosyal medya farklı geçmişlerden gelen kullanıcılar arasında ilişki kurmaya izin vererek sürdürülebilir bir sosyal } \\
\text { yapıya neden olur }\end{array}$ \\
\hline Martín-Consuegra vd. (2019) & $\begin{array}{l}\text { Sosyal medya, markaların anlık bilgi alışverişi, paylaşımı ve etkileşimler için hedef kitleye iki yönlü iletişim } \\
\text { platformu olarak kullandığı, tüketiciler ve marka sadakati için güvenilir deneyimler yaratan ağlardır }\end{array}$ \\
\hline
\end{tabular}

Kaynak: Colella vd., 2019:33.

Sosyal medya, işletmelere potansiyel ve mevcut tüketicilerle etkileşim kurma, müşterilerle daha derin ve anlamlı ilişkiler kurma firsatı sunar. Bu, özellikle en ufak bir hata nedeniyle tüketici güveninin kaybedilebildiği, belirli bir ürün, hizmet, marka veya şirket hakkında olumsuz geri bildirimlerin ve bilgilerin yayılmasına yol açabilecek günümüz iş ortamında önemlidir (Ziyadin vd., 2019:2-3).

Sosyal medya, kamusal etkileşim yoluyla internet üzerinde içerik etkileşimi ve dolaşımı için tasarlanmış medyadır (Glendah vd., 2019:50). Sosyal medya ve sosyal ăg terimleri genellikle birbirlerinin yerine kullanılmasına ve bazı örtüşmelere sahip olmalarına rağmen, gerçekte aynı değildirler. Sosyal medya, mesaj ileten bir iletişim kanalı olarak işlev görür. Sosyal ağ, birkaç taraf arasında bilgi paylaşımını içeren iki yönlü ve doğrudan iletişimdir. Sosyal ağ sitelerinin çeşitli tanımları vardır. Kullanıcı katılımı ve kullanıcı tarafından oluşturulan içerik birçok tanımın ortak unsurudur. Sosyal medya, sosyal ağların oluş̧uğu ortamdır (Belfiore vd., 2019:45-46; Paquette, 2013:3). Sosyal medya, insanların mesajla ve ortam aracılığıla birbirleriyle nasıl etkileşime girdikleri ile ilgilidir. Kullanıcılar, iletinin içeriğini oluşturmaya aktif olarak katılmaktadır. Bu içerik oluşturma, sosyal medyanın güçlü ve benzersiz bir odağıdır (Bateman vd., 2019:100-101).

Sosyal medya, tüketicilerin davranışlarını şekillendirmede, markaları sosyal medyaya daha fazla ve geleneksel pazarlama faaliyetlerine daha az kaynak ayırarak pazarlama iletişimi stratejilerini değiştirmeleri konusunda önemli bir rol oynamaktadır. Markalar, tüketicilerin zihninde güçlü ve olumlu marka bilgisi oluşturmak için, ürün/hizmetleriyle ilgili bilgileri Facebook, Instagram, Twitter ve YouTube vb. sosyal medya platformlarında paylaşmaya ağırlık vermektedir. Sosyal medya platformlarının etkileşimli doğası, tüketici-marka etkileşimini teşvik etmektedir. Bu da, tüketici-marka ilişkisinin geliştirilmesinde faydalıdır (Cheung vd., 2019:1; Bae ve Zamrudi, 2018:851).

Global Index, genç kullanıcıların markaları ve ürünleri araştırırken sosyal medyaya yönelme olasılığının daha yüksek olduğunu ve sosyal ağların arama motorlarını 16 ila 24 yaş arasındaki insanlar için en popüler çevrimiçi araştırma yöntemi olarak kullandığını bildirmektedir. Benzer şekilde, 16 ile 64 yaşları arasındaki dünyadaki internet kullanıcılarının \%43'ü satın alacakları ürünü araştırırken sosyal ağları kullandıklarını söylemektedir. 2019 yılında dünya genelinde tüketici e-ticaret kategorilerinde harcanan toplam miktarlar (https://wearesocial.com/, E.T.: 01.01.2020):

- Moda ve güzellik - 620.1 milyar \$.

- Elektronik ve fiziksel medya - 456.9 milyar \$. 
- Yemek ve kişisel bakım - 168.8 milyar \$.

- Mobilya ve ev eşyaları - 316.7 milyar \$.

- Oyuncak ve hobiler - 383.2 milyar \$.

- Seyahat - 1.19 trilyon \$.

- Dijital müzik - 13.59 milyar \$.

- Video oyunları - 83.15 milyar \$,

olarak gerçekleşmiştir.

\section{SOSYAL MEDYA KANALLARI}

Sosyal ağlar sosyal medyanın temel türüdür. Sosyal ağlar, topluluklar arasındaki güvenin artmasına katkıda bulunan iletişim ve etkileşim platformlarıdır. Kullanıcıların görüşlerini, içeriklerini paylaşmalarını, etkileşimi ve topluluk oluşturmayı teşvik etmelerini sağlayan herhangi bir web sitesi veya çevrimiçi platform bir sosyal ağ olarak sınıflandırılabilir (Ziyadin vd., 2019:2). En popüler sosyal ağlar arasında Facebook, Instagram, YouTube, Twitter, WhatsApp, Telegram bulunmaktadır (Ajina, 2019:1514). Son on y1lda, sosyal medya en büyük iletişim ve pazarlama araçlarından biri haline gelmiştir. Standart bir sosyal medya yapısı mevcut değildir ve sosyal medya siteleri işlevlerinde ve özelliklerinde farklılık gösterir (Chiang vd., 2019:114-115). Tablo 2'de farklı sosyal medya kanallarının tanımları ve örnekleri verilmiştir.

Tablo 2. Farklı Sosyal Medya Kanallarının Tanımları ve Örnekleri

\begin{tabular}{|c|c|c|}
\hline $\begin{array}{l}\text { Sosyal } \\
\text { Medya } \\
\text { Kanalları }\end{array}$ & Tanım & Örnek \\
\hline Mikro blog & Temel olarak metin tabanlı ve kelime sınırlaması dışında bloglarla işlevini gören blog türü & $\begin{array}{l}\text { Twitter, Tumblr, Sina Weibo, } \\
\text { Tencent Weibo }\end{array}$ \\
\hline Blog & $\begin{array}{l}\text { Bloggerların günlük tutmasına, kişisel deneyimlerini paylaşmasına, belirli bir alandaki bilgileri } \\
\text { paylaşmasına, yorum göndererek okuyucularla etkileşime geçmesi olanak tanır. }\end{array}$ & Blogger, Sina Blog, Blogbus \\
\hline $\begin{array}{l}\text { Sosyal A } \breve{g} \\
\text { Siteleri (SNS) }\end{array}$ & $\begin{array}{l}\text { İnsanların kişisel profiller oluşturdukları, gerçek dünyada tanıyabilecekleri veya bilmedikleri } \\
\text { diğer kullanıcılarla sanal olarak tanıştıkları, bağlantı kurdukları, iletişim kurdukları ve ilişkiler } \\
\text { geliştirdikleri web siteleri. Fotoğraf veya video paylaşım özellikleri gibi farklı özellikler içerir. }\end{array}$ & $\begin{array}{l}\text { Facebook, My Space, } \\
\text { LinkedIn, Renren, Douban }\end{array}$ \\
\hline Sanal dünya & $\begin{array}{l}\text { Sanal oyun dünyalarını ve sanal sosyal dünyayı içerir. 3D ortamda gerçek dünyaya benzeyen } \\
\text { çevrimiçi uygulamalardır. Bir resim veya özelleştirilmiş insan benzeri bir karakterle temsil edilen } \\
\text { kullanıcılar, oyunların kuralları tarafından kısıtlanmadığı sürece kendi servetlerini oluşturabilir } \\
\text { veya sanal dünyadaki diğerleriyle etkileşime girebilir }\end{array}$ & $\begin{array}{l}\text { Second Life, World of } \\
\text { Warcraf, 51.com }\end{array}$ \\
\hline Ortak Projeler & $\begin{array}{l}\text { Kollektif zekadan oluşur ve içeriğinin çalışması için kullanıcılara oldukça bağımlıdır. İki ana tipte } \\
\text { sınıflandırılmıştır: Vikisözler ve sosyal yer imi siteleri. Herhangi bir kullanıcının içeriği } \\
\text { geliştirmesine veya yanlış olduğuna inanılan içeriğin itiraz ederek düzenlemesine izin verir }\end{array}$ & $\begin{array}{l}\text { Wikipedia, } \quad \text { Delicious, } \\
\text { baidu.com }\end{array}$ \\
\hline $\begin{array}{l}\text { İçerik } \\
\text { Toplulukları }\end{array}$ & $\begin{array}{l}\text { Kişilerden gelen metin, fotoğraf, video ve sunum slaytları gibi materyallerin paylaşılması için } \\
\text { tasarlanmıştır. Video ve müzik paylaşım siteleri, bir tür içerik topluluğu olarak sayılabilir. }\end{array}$ & YouTube, Youku, Tudou \\
\hline $\begin{array}{l}\text { Geribildirim } \\
\text { için Adanmış } \\
\quad \text { Siteler }\end{array}$ & $\begin{array}{l}\text { Kullanıcıların sayısız konuda deneyim, görüş ve düşünce paylaşmasına, okumasına, incelemesine, } \\
\text { yanıtlamasına, tartışmasına ve paylaşmasına olanak tanıyan web siteleri. Bulletin Boards } \\
\text { Sistemleri ve çevrimiçi forumlar iki ana tiptir. }\end{array}$ & $\begin{array}{l}\text { TripAdvisor, Yelp } \\
\text { dianping.com, tianya.com, } \\
\text { mafengwo.com }\end{array}$ \\
\hline $\begin{array}{l}\text { Mobil Sosyal } \\
\text { Uygulamalar }\end{array}$ & $\begin{array}{l}\text { Mobil cihazların çeşitli hizmetler sunmak için artan gücünden faydalanan yeni bir paradigma. } \\
\text { Mobil Sosyal Uygulamalar, birbirine bağlı kişiler arasındaki sosyal etkileșimleri destekler. }\end{array}$ & WhatsApp, WeChat \\
\hline
\end{tabular}

Kaynak: Yang ve Wang, 2015:169; Walaski, 2013:40-41. 


\section{WEB 2.0}

Web 2.0 terimi, ilk kez 2004 y1lında O'Reilly Media ve Media Live International tarafından düzenlenen bir konferansta kullanılmıştır. Web 2.0'1n genel olarak kabul edilmiş bir tanımı yoktur. En yaygın kullanılanlardan biri, kullanıcı katılımı, açıklık ve ağ etkileri ile karakterize edilen olgun bir ortam, internetin gelecek nesillerine kolektif olarak temel oluşturan bir dizi ekonomik, teknolojik ve sosyal eğilimleridir. Kullanıcılar veri ve hizmetleri başkalarının onları tekrar harmanlamasına izin verecek şekilde sağlar, böylece katılım mimarisi ile bir etki ağı oluşturur (Orenga-Rogla ve Chalmeta, 2019:4). Web 2.0, sosyal ağlar, bloglar ve mesaj panoları gibi kullanıcı tarafından oluşturulan içeriğe sahip internet alanlarını ifade etmektedir (George ve Lewenstein, 2019:99). Web 2.0 teknolojisi, metin, grafik, ses ve sosyal ağda paylaşılan içerik sunar. Çevrimiçi etkileşim ve işbirliği şeklini değiştiren ikinci nesil internet hizmetlerini temsil eder. Yeni nesil Web 2.0 araçları, kullanıcıların aktif katkıda bulunduğu ve içerik üreticileri haline geldiği katılımcı yaklaşımları teşvik eder (Hazari vd., 2019:188).

Web 2.0, iş ve sosyal süreçlerde katılımcı olarak kullanıcıların bilgilerini, deneyimlerini ve pazar gücünü genişleten açık kaynaklı, kullanıcı kontrollu ve etkileşimli çevrimiçi uygulamaların bir koleksiyonudur. Bilgi içeriğinin verimli bir şekilde üretilmesine, yayılmasına, paylaşılmasına ve düzenlenmesine / rafine edilmesine izin vererek fikir ve bilgi akışını kolaylaştırmaktadır (Brennan ve Croft, 2012:3). Çevrimiçi bloglar, forumlar ve sosyal ağ siteleri gibi Web 2.0 teknolojilerinin yükselişi, yalnızca internet kullanıcıları arasındaki iletişim araçlarını değil, aynı zamanda tüketicilerin satın aldıkları markalarla etkileşime girme biçimlerini de önemli ölçüde değiş̧irmiştir. Son araştırmalar, sosyal medyaya yönelik pazarlama bütçelerinin sürekli büyüdügünü göstermektedir. $\mathrm{Bu}$ da, markaların popüler sosyal medya platformlarında marka sayfaları oluşturarak sosyal medyada yer almayla daha fazla ilgilenmelerine yol açmaktadır (Tsimonis ve Dimitriadis, 2019:2; Constantinides, 2014:42).

Dijital bilgi ve iletişim teknolojileri, toplumların sosyal ve kültürel yaşamını büyük ölçüde etkilemekte ve özellikle Web 2.0 teknolojilerinin geliştirilmesi yeni düşünme, bilgilendirme, iletişim kurma yollarına olanak sağlamaktadır (Pinheiro, 2020:1). Webloglar, wikiler, Twitter gibi sosyal medya araçlarının artan popülaritesi, Web 2.0 yazılımını karakterize eden özelliklerin sonucudur. Bu tür dijital araçlar kullanıcı dostu, kişiselleştirilebilir, içerik oluşturma ve değiştirmeye izin verir. Ayrıca, sosyalleşme, paylaşım ve işbirliği için buluşma yerleri olabilirler (McLoughlin ve Alam, 2019:125).

Harris ve Rea (2019), Web 2.0 teknolojilerini, 5 temel kategoride sınıflandırmıştır. Buna göre (Harris ve Rea, 2019:138);

1. Wiki: Erişimi basitleştirilmiş bir biçimlendirme dili kullanarak içeriğe katkıda bulunma veya içeriği değiştirme olanağını sağlamak için tasarlanmış web sayfaları topluluğudur. Genellikle ortak web siteleri oluşturmak için kullanılır. En iyi bilinen örneklerinden biri Wikipedia'dır. Wikisözler de eğitimde öğrenciler tarafından desteklenen bilgi sistemlerini kolaylaştırmak için kullanılabilir.

2. Blog: Web günlüğ̈̈ (blog), genellikle düzenli yorum girişleri, etkinlik açıklamaları veya grafik/ video gibi diğer materyalleri olan bir kişi tarafından tutulan bir web sitesi türüdür.

3. Podcast: RSS beslemelerini işleyebilen bir yazılım kullanarak internetten ücretsiz olarak indirilebilen bir dijital medya dosyası, genellikle dijital ses veya videodur. Dosya daha sonra kişisel bir bilgisayarda veya mobil cihazda oynatılabilir. YouTube, şu anda podcast yayınlamak ve görmek için en popüler sitedir. Ses podcastları genellikle mp3 dosyasıdır ve en yaygın podcast türüdür. Video podcastlar çeşitli formatlarda olabilir, ancak mpeg-4 en yaygın olanıdır. Podcastların popülaritesinin nedeni, dizüstü bilgisayarlar, ipodlar, cep telefonları, mp3 çalarlar veya diğer taşınabilir cihazlar kullanılarak çalınabilmeleridir.

4. Sosyal Ăg: Genellikle bir veya daha fazla bağımlılık şekliyle bağlanan bireylerden veya kuruluşlardan oluşan sosyal bir yapıdır. Facebook ve MySpace en büyük sosyal ağlar arasındadır. Twitter, kullanıcılarının tweet olarak bilinen mesajları göndermesine ve okumasına olanak sağlayan birleşik bir sosyal ağ ve mikro blog hizmetidir.

5. Sanal Dünya: Kullanıcıların coğrafi sınırlar olmadan birbirleriyle etkileşime girmesini sağlayan bilgisayar simülasyonlu bir ortamdır. Her kullanıcı bir avatar ile temsil edilir. Bu avatar, kendisine atanan, kullanıcıya benzeyen (örneğin, cinsiyet, saç rengi, vb.) genel bir temsil olabilir veya daha karmaşık sanal dünyalarda, kullanıcının tercihlerine göre tamamen özelleştirilebilir. Linden Lab'ın 
Second Life'ı (SL), şu anda 15 milyondan fazla kayıtlı hesapla en büyük sanal dünyadır. Diğer sanal dünyalar ActiveWorlds ve Twinity'dir.

Web 2.0 araçları ile yönetilen bilginin özellikleri ise şu şekilde sıralanabilir (Orenga-Rogla ve Chalmeta, 2019:4):

- Katkı: Her kullanıcı, bilgilerini özgürce sağlama olanağına sahiptir.

- Paylaşma: Bilgi içeriği diğerleri için (güvenlik mekanizmaları aracılığıyla) serbestçe kullanılabilir.

- İşbirliği: Bilgi içeriği, bilgi tedarikçileri arasında işbirliği yoluyla oluşturulur ve korunur.

- Dinamizm: Bilgi içeriği, ortamdaki ve durumdaki değişiklikleri yansıtacak şekilde sürekli güncellenir.

- Güvenilirlik: Bilginin katkısı, bilgi tedarikçileri arasında güvene dayanmalıdır.

Sosyal medyanın önemini bir pazarlama aracı olarak ele almak için, kullanıcılar tarafından World Wide Web'in yeni geliştirilen kullanım şeklini vurgulamak önemlidir. Yeni kullanım şekli, kullanıcıların aktif olarak katılımını içermektedir. Burada tüketiciler dijital içeriğin oluşturulmasına ve tüketimine sürekli katılmaktadır. Bu sayede, kullanıcılar sadece bilginin pasif izleyicileri değil aynı zamanda internet platformlarının katma değer sağlayıcıları haline gelmektedir (Bae ve Zamrudi, 2018:852).

\section{SOSYAL MEDYA PAZARLAMASI}

Literatür, sosyal medya pazarlaması için farklı tanımları ortaya koymaktadır. Sosyal medya pazarlaması, sosyal ağların kullanımı yoluyla tüketicilerin daha fazla dikkat ve katılımı teşvik eden yeni nesil bir pazarlama aracıdır. Sosyal medya pazarlaması, tüketicilerle iki yönlü iletişimi kolaylaştırmak için sosyal platformlarla ilgilenen bir pazarlama stratejisidir (Dwived vd., 2015:4-5). Sosyal medya pazarlaması, sosyal medya aracılığıla markaya dikkat çekme sürecidir. Ayrıca, sosyal medya pazarlaması, kullanıcıların dikkatini çekecek ve onları okuyucularıyla paylaşmaya teşvik edecek içerik oluşturmayı amaçlamaktadır. Sosyal medya, ortak ilgi alanlarına fikirleri paylaşmak ve tartışmak için sanal bir alan sağlar. Sosyal ağlar, kullanıcıların sürekli iletişim yoluyla bir topluluk oluşturmasına olanak tanır. Sosyal medya pazarlama, pazarlama iletişimi ve markalaşma hedeflerine ulaşmak için çeşitli sosyal medya platformlarında kullanılan bir internet pazarlama türüdür (Ziyadin vd., 2019:2). Sosyal medya pazarlaması, tüketicilerin satın alma davranışlarını olumlu yönde etkilemek için sosyal medyayı kullanan ticari pazarlama etkinlikleri veya süreçleridir (Chen ve Lin, 2019:22).

Sosyal medya pazarlaması, ağızdan-ağıza pazarlama ilkelerini kullanarak çevrimiçi platformlarda tüketiciler arasında marka bilinirliğini artırmak için mevcut sosyal medya platformlarının kullanımıdır. Bu nedenle, iki tanıtım biçimini destekler:

1. Şirketlerin müşterileriyle olan iletişimini ifade eden geleneksel pazarlama tanıtımı.

2. Sosyal medya platformları için benzersiz olan ve tüketiciden-tüketiciye iletişim içinde yer alan sosyal tanitım.

Sosyal medya pazarlaması, işletmelerin satış yapmaya çalışmaktan tüketicilerle bağlantı kurmaya geçmek zorunda kaldıkları ilişki pazarlamasıyla da ilgilidir (Farook ve Abeysekara, 2016:116). Sosyal medya pazarlamas1, 21. yüzyıl ticaretinin ayrılmaz bir unsurudur (Felix vd., 2017:118).

Sosyal medya pazarlaması ile yakın anlamda kullanılan dijital pazarlama, çeşitli dijital kanalları kullanarak farkındalık yaratmanın yanı sıra marka, ürün veya hizmetleri çevrimiçi olarak tanıtmak anlamına gelir. Dijital pazarlama, internet tabanlı ve internet tabanlı olmayan kanallar da dahil olmak üzere tüm dijital platformlar aracılığıyla tanıtım yapılmasıdır. Sosyal medya pazarlama, ürün veya markayı tanıtmak için sosyal medya sitelerini, forumları ve blogları kullanan bir pazarlama şeklidir. Dijital pazarlama geleneksel pazarlamaya göre daha hesaplıdır, ancak sosyal medya pazarlamasından daha pahalıdır. Sosyal medya, işletmelerini ücretsiz olarak tanıtmak için herkesin erişebileceği bir platformdur. Dijital pazarlamanın diğer avantajı, tıklama veya ziyaret veya gösterim başına harcama yapmaktır. İşletmenin pazarda büyümesi ve sürdürülmesi için uygun maliyetli bir araçtır (Poddar ve Agarwal, 2019:50-51). Sosyal medya pazarlamasının temel taşları, müşteriler, kaynaklar ve ulaşılmak istenen hedeflerdir. Sosyal medya pazarlaması dijital pazarlamanın önemli bir aracıdır (Paswan, 2018:8).

Sosyal medya pazarlamasının amaçları; satış ve marka bilinirliğini artırmak, marka imajını güçlendirmek, tüketicilerin çevrimiçi platformlara ziyaretlerini teşvik etmek, pazarlama maliyetleriyle ilgili kaygıları gidermek, 
içerik üretmeye teşvik ederek sosyal medyada kullanıcı etkileşimi oluşturmak şeklinde özetlemek mümkündür. Sosyal medya pazarlaması, internet ve etkileşimli teknolojilerin kullanılabilirliği ile mümkün olmaktadır. Erişilebilirliği, geniş bir kitleye ulaşmada etkinliğinin yanı sıra marka bilinci oluşturma avantajları nedeniyle, sosyal medya pazarlaması çok sayıda kuruluş ve işletme tarafından kullanılmaktadır (Raut ve Kulkarni, 2020:28; Shaiful vd., 2019:157).

\section{SOSYAL MEDYA PLATFORMLARI}

Facebook 1 milyar aylık aktif kullanıcı sayısını aşan ilk sosyal ağdır ve 2019'un ikinci çeyreği itibarıyla dünya çapında 2.41 milyar aylık aktif kullanıcıya sahiptir. Platform, aynı zamanda dünyadaki en popüler sosyal ağlar arasında ilk sırada yer almaktadır. Dünya çapındaki sosyal ağlarda aylık aktif kullanıcı sayısının 2021 yılına kadar 3.02 milyara ulaşması; 2023 yılında bu kullanıcıların yaklaşık 800 milyonunun Çin'den ve 450 milyonunun Hindistan'dan gelmesi beklenmektedir. Diğer taraftan ortalama olarak, küresel internet kullanıcıları sosyal ağlarda sörf yapmak için günde 136 dakika harcamaktadır. Bu durum da, markaları ve pazarlamacılarını sosyal medya pazarlaması veya sosyal reklamcılık yoluyla çeşitli ürün/hizmetleri tanıtmak için sosyal medya platformlarını daha fazla kullanmaya yönlendirmektedir (https://www.statista.com/, E.T.: 25.02.2020). Grafik 1, aylık etkin kullanıcıları, etkin kullanıcı hesaplarını, reklam kitlesini temel alarak (milyon olarak) dünyada en çok kullanılan sosyal medya platformlarını göstermektedir (https://wearesocial.com/, E.T.: 22.02.2020).

Grafik 1. Sosyal Medya Platformları

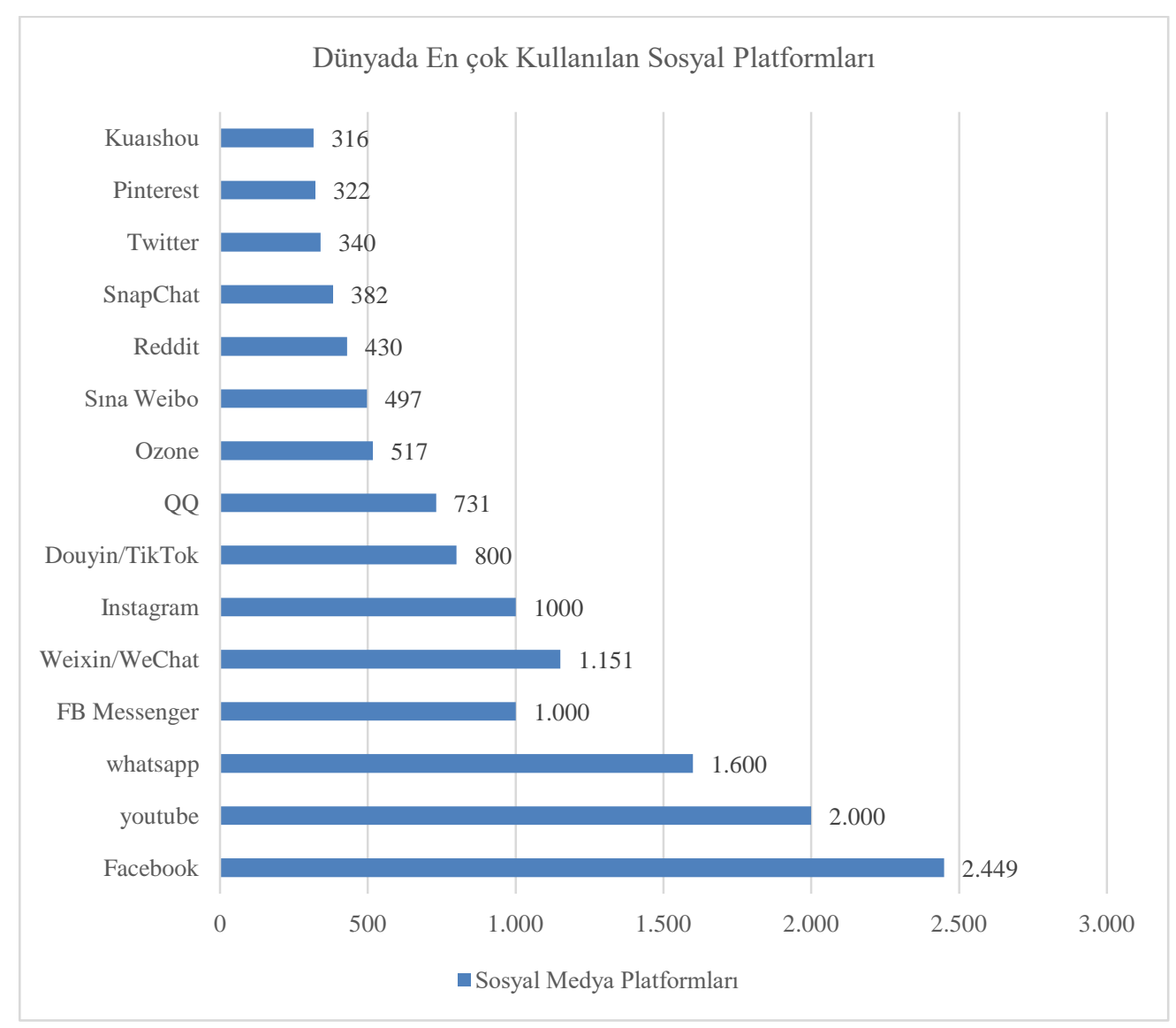

Kaynak: https://wearesocial.com/ (Erişim Tarihi: 22.02.2020).

\subsection{Facebook}

Facebook, Mark Zuckerberg tarafından 2004 y1lında oluşturulan bir sosyal ağ hizmetidir. Başlangıçta sadece Harvard öğrencileri arasında bir iletişim aracı olarak tasarlanmış olsa da Facebook şimdi dünya çapında en büyük sosyal ağ konumundadır. 2019'un 4. çeyreği itibarı ile aylık 2.5 milyardan fazla küresel aktif kullanıcısı bulunmaktadır ve toplam 2.89 milyar kullanıc1, şirketin temel ürünlerinden biri olan Facebook, WhatsApp, Instagram ve Messenger'a aylık olarak erişmektedir. Facebook Şubat 2012'de halka arz edilmiştir. Eylül 2012'de 1 milyar \$ karşılığında Instagram'ı, Şubat 2014'te, 19 milyar \$ karşılığında WhatsApp'1 satın almıştır. 
Hindistan, 260 milyondan fazla kullanıcısıyla Facebook'ta kitle büyüklüğü açısından lider ülkedir. Bu bağlamda, Hindistan'daki Facebook kullanıcıları eğer bir ülke olsaydı, dünyada nüfus açısından en büyük dördüncü ülke olacağını söylemek mümkündür. Hindistan dışında, her biri 100 milyondan fazla Facebook kullanıcısı olan diğer pazarlar sirasıyla 180 milyon, 130 milyon ve 120 milyon Facebook kullanıcisı olan ABD, Endonezya ve Brezilya'dır. Facebook'un geliri 2013'te 7.87 milyar \$'dan, 2018'de 70.7 milyar \$'a yükselmiştir. 2018'de, 18.49 milyar \$ net gelir elde ederek, y1llık gelirlerde sosyal medya şirketleri arasında ilk sirada yer almıştır (https://www.statista.com/, E.T.: 16.03.2020).

Facebook, \%61'i 25 ile 54 yaşları arasında Amerikalılar olmak üzere aylık 2 milyardan fazla aktif kullanıcıyla açık arayla en büyük sosyal medya platformudur. Facebook potansiyel satışlar, reklam ve hedefleme stratejileri için uygundur. Facebook ayrıca müşterilerle ilişkiler kurmak, işletmelerin imajını güçlendirmek ve müşteri adaylarını, müşterilere ve sadık takipçilere dönüştürmek için de kullanılabilir. Facebook için birçok farklı içerik türü mevcuttur. Ancak anahtar, işletmenin farklı bir yönünü gösteren içeriktir (https://digitalmarketinginstitute.com/, E.T.: 12.03.2020).

\subsection{Twitter}

Twitter, kullanıcıların tweet adı verilen 280 karakterlik kısa mesajlar göndermelerini sağlayan çevrimiçi bir sosyal ağ hizmetidir. 2019'un 4. çeyreği itibarı ile Twitter'ın dünya çapında günlük etkin kullanıcı sayısı 152 milyondur. 2019 yılında, şirketin geliri 1.47 milyar \$'ın üzerinde net gelirle 3.46 milyar ABD dolarına ulaşmıştır. Şirket, Kasım 2013'te halka açılmış ve Eylül 2019 itibarıyla piyasa değeri yaklaşık 33 milyar \$'a ulaşmıştır. Ocak 2020 itibariyle mikroblog hizmeti Twitter'ın ABD'de 59.35 milyon kullanıcısı bulunmaktadır. Japonya ve İngiltere sırasıyla 45.75 ve 16.7 milyon kullanıcıyla ikinci ve üçüncü sırada yer almaktadır. Twitter, iç ve dış politikada giderek daha çok kullanılan bir araç haline gelmiştir. Platform, vatandaşlar ve diğer yetkililerle etkileşime girmenin etkili bir yoludur. Çoğu dünya lideri ve dişişleri bakanlarının resmi bir Twitter hesabı mevcuttur. 2019'da sosyal ağın yıllık gelirleri, önceki yılki 3.04 milyar \$'dan, yaklaşık 3.46 milyar ABD dolarına ulaşmıştır. Ayrıca, 2019'da reklam hizmetlerinden 2.99 milyar \$'dan fazla gelir elde etmiştir (https://www.statista.com/, E.T.: 06.03.2020).

\subsection{WhatsApp}

WhatsApp, mobil cihazlar için platformlar arası bir anlık mesajlaşma servisidir. WhatsApp, 2019 itibariyle aylık yaklaşık 1.6 milyar aktif kullanıcısı ile dünya çapında en popüler küresel mobil mesajlaşma uygulamasıdır. 1.3 milyar kullanıcısı olan Facebook Messenger'1 ve 1.1 milyar kullanıcısı olan WeChat'1 geride birakmaktadır. Facebook ve YouTube'dan sonra dünyadaki en popüler üçüncü sosyal ağdır. Bununla birlikte, ABD'de WhatsApp kullanıcı sayısının 2023'te 85.8 milyon kullanıcıya ulaşması beklenmektedir. Düşük maliyetli bir abonelik modeline dayanan WhatsApp, özellikle uluslararası veya grup mesajları için sms yoluyla operatör tarafindan faturalandırılan kısa mesajlara ucuz bir alternatiftir. Mobil mesajlaşma uygulaması, kullanıcıların metin, resim, video, sesli mesaj paylaşmasını sağlar ve video görüşmesini de destekler. Facebook satın alımından elde ettiği kar nedeniyle, WhatsApp kurucusu Jan Koum şu anda dünya çapında sosyal medya milyarderleri arasında Mart 2019 itibariyle tahmini 9.6 milyar \$ değerinde kişisel servetiyle üçüncü sırada yer almaktadır (https://www.statista.com/, E.T.: 16.02.2020). Ayrıca uygulamanın, kullanıcılarına 24 saat sonra kaybolan fotoğraf, video veya metin içeren paylaşım yapmasına izin veren Whatsapp durum özelliği de bulunmaktadır (https://influencermarketinghub.com/, E.T.: 14.03.2020).

\subsection{Youtube}

2005 yılında kurulan YouTube, müzik videoları, video blogları, her konuda eğitici videolar, TV klipleri gibi kullanıcı tarafından oluşturulan ve kurumsal medya içeriğine sahip dünya çapında en büyük çevrimiçi video platformudur. 2018'in dördüncü çeyreği itibarı ile, dünya çapındaki internet kullanıcılarının \%27'si günde en az bir kez YouTube'a erişmiştir. 2018'de çevrimiçi video portalının ABD net video reklam geliri, 2016'daki 2.16 milyar \$'dan, 3.36 milyar \$'a ulaşmıştır. YouTube aynı zamanda hem Google Play'de hem de dünya çapında Apple App Store'da en popüler mobil uygulamalar olarak yer almaktadır. Platformun bağımsız mobil uygulaması YouTube Music, dünya çapında en çok indirilen mobil eğlence uygulamaları arasında yer almıştır. May1s 2019'dan itibarıyla YouTube'a her dakika 500 saatlik video yüklenmiştir. Bu, saatte yaklaşı 30.000 saatlik yeni yüklenen içeriğe eşittir. Her 60 saniyede bir yüklenen video içerik saatlerinin sayısı, 2014-2019 
arasında yaklaşık \% 40 artmıştır. ABD nüfusunun \% 68'i YouTube'u müzik videoları izlemek veya müzik dinlemek için kullanmaktadır. Bu oran 12 ile 24 yaşları arasında \% 91'e çıkmaktadır (https://www.statista.com/, E.T.: 03.03.2019).

\subsection{Instagram}

Instagram, kullanıcıların fotoğraf çekmelerine ve bunları bir dizi dijital filtre ile düzenlemelerine olanak tanıyan bir fotoğraf paylaşım uygulamasıdır. Instagram ayrıca video paylaşımı ve Snapchat'in hikayeleri ile rekabet eden Instagram hikayeleri de sunmaya başlamıştır. Haziran 2018 itibariyle, Instagram dünya çapında aylık 1 milyardan fazla ve günlük 500 milyon aktif kulllanıcı bildirmiştir. 120 milyondan fazla aktif Instagram kullanıcısı ile ABD, en büyük pazardır. Genel olarak, kullanıcılar içeriklerini Facebook, Twitter, Flickr ve Tumblr gibi çeşitli sosyal ağlarda kolayca paylaşabildikleri için Instagram, güçlü bir sosyal entegrasyondan yararlanır. 2020'nin dördüncü çeyreğinde, Instagram'ın küresel gelirlerde 6.8 milyar \$'a ulaşacağı tahmin edilmektedir. Bu sayı, 2019'un ikinci çeyreğinde tahmini 3.3 milyar \$'dır. Eylül 2019 itibarı ile ABD'deki en popüler sosyal ağlara bakıldığında, bu ay boyunca kullanıcılar, Facebook' ta ortalama $769.16 \mathrm{dk}$, Instagram'da 202.95 dk, Tik tok'ta 498.09 dk, Whatsapp'ta 292.4 dk, Snapchat'ta $199.95 \mathrm{dk}$, Twitter'da $158.2 \mathrm{dk}$, Pinterest'te $68.64 \mathrm{dk}$, Wechat'te $70.61 \mathrm{dk}$, Google Messenger'da $335.51 \mathrm{dk}$ ve Telegram'da $274.33 \mathrm{dk}$ geçirmiştir (https://www.statista.com/, E.T.: 12.03.2020). Ayrıca, Instagram kullanıcıların \% 63 'ü 18 ile 34 yaşları arasında bulunmaktadır (https://www.searchenginejournal.com/, E.T.:05.03.2020).

\subsection{Snapchat}

Snapchat, Evan Spiegel, Bobby Murphy ve Reggie Brown tarafından Eylül 2011'de piyasaya sürülen bir mobil fotoğraf mesajlaşma ve multimedya paylaşım uygulamasıdır. Snapchat, ABD'de gençler ve genç yetişkinler arasında en popüler sosyal medya platformu olarak yer almaktadır. Mayıs 2015'te dünya çapında 100 milyon günlük aktif kullanıcı bildiren şirket, 2019'un 4. çeyreğinde, günlük 218 milyon aktif kullanıcıya ulaşarak en hızla büyüyen sosyal ağlardan biri haline gelmiştir. Snapchat'in temel özelliği, bir fotoğraf veya kısa bir videodan oluşabilen ve metin, filtreler, çıkartmalar veya diğer kaplamalarla düzenlenebilen, anlık fotoğraf adı verilen multimedya mesajlarının oluşturulmasıdır. Platform ayrıca gençlere ve milenyum jenerasyonuna yönelik sosyal medya pazarlamasının temel taşı haline gelmiştir. 2019'in 4. çeyreğinde, Snapchat'ın geliri 560.9 milyon \$’a ulaşmıştır (https://www.statista.com/, E.T.: 05.03.2020).

\subsection{LinkedIn}

LınkedIn, 610 milyon kullanıcısıyla, aktif kullanıcılar açısından en popüler sosyal ağlardan biridir. 200'den fazla ülkede bulunan web sitesi, şirketlerin çevrimiçi sayfalar üzerinden kendilerini sunmalarına ve kullanıcıların iş ilanlarını bulmalarına ve uzmanlık alanlarındaki bağlantılarını geliştirmelerine olanak tanımaktadır. LinkedIn, Aralık 2016'da Microsoft tarafından yaklaşık 26.2 milyar \$ karşılığında satın alınmış ve bu da Microsoft'un bugüne kadarki en pahalı satın alması olmuştur. LinkedIn, üç farklı kaynaktan gelir elde etmektedir. İşe alma çözümleri, şirketin gelirine en büyük katkıyı sağlamakta, bunu reklam ve premium abonelikler izlemektedir. LinkedIn'in 2018 yılındaki yıllık segment geliri 5.26 milyar \$’1 aşmıştır. LinkedIn, sosyal işe alım kanalları arasında çevrimiçi işe alım için çok etkili bir araç olarak kabul edilir ve bir adayı başarılı bir şekilde yerleştirmede en yüksek kullanım oranına sahiptir. Ocak 2018 itibarıyla ABD'de yıllık 100.000 \$ ve daha fazla gelir elde eden internet kullanıcılarını \%60' gelirleri 2011'den 2015 yılları arasında 155.9 milyondan 581.3 milyon \$'a yükselmiştir. 2016'nın üçüncü çeyreğinde, LinkedIn'in toplam geliri 959.8 milyon \$ olarak gerçekleşmiştir (https://www.statista.com/, E.T.: 25.02.2020).

LinkedIn genellikle B2B işletmeleri için bir seçim platformudur. İşe alımların yanısıra, işletme satışlarını arttırmak, marka imajını güçlendirmek, editoryal içerik oluşturmak için de kullanılmaktadır. LinkedIn'deki demografi diğer sitelerden farklıdır. 30 ila 49 yaşları arasında, 30 yaşın altındaki kullanıcılardan daha fazla kullanıcı vardır (https://digitalmarketinginstitute.com/, E.T.: 12.03.2020). LinkedIn, en hızlı sosyal medya ağı olmasa da, fark yaratabilecek seçkin profesyonel gruplarıyla bağlantı kurmak için sınırsız bir potansiyel bulundurmaktadır (https://www.searchenginejournal.com/, E.T.: 05.03.2020). 


\subsection{Pinterest}

Sosyal ağ sitesi Pinterest, tarihte 10 milyon aylık ziyaretçiye en hızlı ulaşan sitedir. 2019'un dördüncü çeyreği itibarı ile, platformun dünya çapında aylık 335 milyon aktif kullanıcısı bulunmaktadır. 2019 Nisan'ında New York Borsası'nda işlem görmeye başlamıştır. Ekim 2019'da Pinterest'in masaüstü trafiğinin yaklaşık \%43'ü ABD'den gelmekteydi. 2019 yılı itibarı ile, görsel yer imi platformunun ABD'de 88 milyon aylık aktif kullanıcısı bulunmaktadır. Pazar lideri Facebook, Aralık 2019'da ABD'deki tüm sosyal medya sitesi ziyaretlerinin \% 50.68'ini Twitter ise \% 19.03'ünü oluşturmuştur. Sosyal ağlar, Kuzey Amerika'daki en popüler internet etkinliklerinden biridir. ABD'deki internet kullanıcılarının \%79'unun sosyal ağ profili bulunmaktadır ve sosyal ağ kullanıcılarının sayısının 2018'deki 244 milyondan 2023'te 257 milyondan fazla kullanıcıya çıkacağı öngörülmektedir. Aralık 2019'da ABD sosyal medya ziyaretlerinin Pinterest pazar pay1 \%19.18'dir. 2019 ilk çeyreği itibariyle, e-ticaret web sitelerine sosyal medya yönlendirme trafiğinin yüzde \%8.2'i Pinterest, \%80.4'ü ise Facebook üzerinden gerçekleşmiştir. Pinterest kullanan ABD pazarlamacılarının payı ise \%28'dir. 2019 üçüncü çeyreği itibarıyla Pinterest'a erişen erkek ABD internet kullanıcılarının oranı \%16, kadın kullanıcıların oranı ise \%49'dur (https://www.statista.com/, E.T.: 04.03.2020).

Pinterest kullanıcıların \%90'ından fazlası platformu kullanarak satın alma yapmayı planladığı için işletme satışlarını arttırmak için de kullanılmaktadır. Ayrıca, güzel ve çarpıcı dekor, yemek, sanat, moda, düğün, seyahat fotoğrafları gibi konulardan yararlanabilecek işletmelere katkıda bulunan resim ve grafik ağırlıklı bir platformdur (https://digitalmarketinginstitute.com/, E.T.: 12.03.2020).

\section{SOSYAL MEDYA PAZARLAMA STRATEJILERI}

Sosyal medya pazarlama stratejisi, işletme hedeflerine ulaşmak için bireyler ve kurumlar arasındaki etkileşimler yoluyla kanalların ve içerik yayılımının konumlandırılması ve kullanılması anlamına gelir. Sosyal medya pazarlama stratejisinin kanal boyutu, bireyler ve işletmeler arasındaki etkileşimler için sosyal medya kanallarının seçilmesidir. Sosyal medya kanallarının seçimi genellikle işletmenin metin, resim ve video girişi gibi içerik stratejileri hakkındaki kararların belirler. Sosyal medya, kullanıcıların eylemleri ve ürettiği içerikler gibi bir ülkenin teknolojisinin, kültürünün ve hükümetinin bir fonksiyonudur. Bu da, uluslararası bir sosyal medya pazarlama stratejisinin farklı ülkelerdeki durumlara göre uyarlanması gerektiğini göstermektedir (Yang ve Wang, 2015:170).

Kurumsal pazarlama stratejisinin bir parçası olarak sosyal medyayı etkin bir şekilde kullanmak, şirketin Web 1.0 mirasının iyi durumda olmasını gerektirir. Kurumsal web sitesi, çevrimiçi müşterinin beklentilerini karşılayan kurumsal platform olarak hizmet verecek konumda olmalıdır. Çünkü sosyal medya pazarlamasının stratejik hedeflerinin çoğu kusursuz bir şirket web sitesinin varlığını gerektirir. Web sitesi işlevsel, verimli, güvenilir, kurumsal olarak entegre ve müşteri odaklı olmalıdır. Firmanın çevrimiçi kurumsal varlığı, kurumsal konumlandırma, kalite, müşteri odaklılık ve imajı yansıtmalı ve iletmelidir. İyi tasarlanmış bir web sitesine sahip olmak bir zorunluluktur. Ancak başarı garantisi değildir. İkinci önemli koşul ise pazarlama organizasyonunun ve şirketin müşteri hizmetlerinin mükemmel olmasıdır. Sadece çevrimiçi değil geleneksel pazarlama aktivitelerine de yansıyan müşteri odaklılık çok önemlidir (Constantinides, 2014:43).

Başarılı bir sosyal medya pazarlama stratejisine giden yol aşağıdaki 11 adım izlenerek oluşturulabilir https://fitsmallbusiness.com/, E.T.: 26.02.2020):

1. Sosyal Medya Hedeflerini Belirlemek: Net bir sayı ve zaman dilimi ile hedefleri yazmak (Örn. Facebook promosyonları aracılığıyla yılın 4. çeyreğinde çevrimiçi satışları \%20 arttırmak vb.).

2. Hangi Sosyal Medya Kanallarının Işletme Için Uygun Olduğunu Belirlemek: Bu adımda, büyük sosyal medya kanalları ve ne için en iyi olduklarını gözden geçirilir (örn. Facebook: geniş bir kitleye ulaşmak, reklam yayınlamak; LinkedIn: profesyonel bağlantılar kurmak, sektör, şirket haberleri veya iş ilanı paylaşmak için vb.).

3. Sosyal Medya Hesaplarını Kurmak: Seçilen sosyal medya kanallarında hesap oluşturmak. Tüm büyük sosyal medya kanalları kurmak için ücretsizdir.

4. Rakiplerin Analizi: İçerik yayınlamadan önce araştırma yapmak, rakiplerin kaç takipçi, beğeni, yorum aldıklarını, hangi içerikleri ne sıklıkla yayınladıklarını not etmek gerekir. Ayrıca hesaplarıyla ilgili beğendiğiniz ve daha iyisini yapabileceğinizi düşündüğünüz noktaları listeleyebilirsiniz. Bu analiz, 
sosyal medya kanallarınıza nasıl yaklaşmak istediğiniz ve kendi hesaplarınız için hangi ölçütleri ayarlayabileceğiniz konusunda iyi bir ilham kaynăg 1 olabilir. Doğrudan rakipleriniz yoksa, işletmenle benzer bir sektörde bulunan diğer hesapları da inceleyebilirsiniz.

5. İşletmenin Ilk Profilini Oluşturmak: İlk profili oluşturmak, işletme bilgileri yazmak, ilgili resimler eklemek, kişi listesini takip etmek ve ilk içeriği paylaşmak anlamına gelir.

6. Sosyal Medya Programı Oluşturmak: Sosyal medya programı, hedeflerinize ulaşmak ve takipçilerinizi büyütmek için önemli olan kaliteli içeriği sosyal medyada sürekli olarak yayınlamanıza yardımcı olacak bir dizi içerik fikirleri takvimidir. Sosyal medya tutarlılık ile ilgilidir. Bu yüzden ideal olarak her gün takipçilerinizle etkileşimde bulunmak için sosyal medyaya yaklaşık 15 ila 20 dakika ayırmanız gerekir. Yaygın bir sosyal medya stratejisi, içeriğinizin yüzde 80'inin yararlı, eğitici veya eğlenceli ve yüzde 20 'sinin satış odaklı olduğu anlamına gelen 80/20 kuralını uygulamaktır.

7. Sosyal Medya Kanallarını Tanıtmak: Sosyal medya kanallarınızı tanıtmak, yeni kanallarınız hakkında söz sahibi olmak anlamına gelir. Böylece daha fazla insan sizi takip eder. Web siteniz, e-posta listeniz, kurum içi tabelalar, diğer sosyal medya kanalları, reklamlar kanallarınızı tanıtmak için kullanabileceğiniz yerler arasındadır.

8. Sonuçları Ölçmek: Kaç takipçi kazandığınızı, web sitenize ne kadar trafik çektiğinizi ve yayınlarınızın ne kadar katılım aldığını görebilirsiniz. Tüm büyük sosyal medya ağları, analiz platformları aracılığıyla metriklere erişmenizi sağlar. Bazı yaygın metrikler: Takipçiler / beğeniler - sosyal medya kitlenizin boyutunu gösterir. Erişim - sosyal medya yayınlarınızı gerçekte kaç kişinin gördüğünü belirtir. Etkileşimler - içeriğinizin aldığı beğenme, yorum ve paylaşma sayısını gösterir. Tıklamalar yayınlarınızın kaç kez tıklandığı belirtir.

9. En İyi Performans Için Optimize Etmek: İşletmenize en fazla tıklamayı, gösterimi ve etkileşimi neyin sağladığına bakmalı ve planlamanızda bu tür yayınlara daha fazla yer vermelisiniz. Optimizasyon, hedeflerinize ulaşmanıza ve aşmanıza yardımcı olmaktadır. Hedefiniz takipçi sayısını büyütmek ise yeni fikirler deneyebilir, etkileşimi arttırmak istiyorsanız içeriklerinize hashtag ekleyebilirsiniz. Metrikler içeriğinizi nasıl optimize edeceğiniz hakkında çok şey söyleyebilir. Ancak bazen en iyi optimizasyon müşterilerinizle doğrudan görüşmelerden gelir. Bu yüzden, hedef kitlenizi anlamaya, onlara değerli veya eğlenceli içerik sunmaya özen göstermelisiniz.

10. Ürünleriniz / Hizmetleriniz Için Promosyonlar Yapmak: Sosyal medya promosyonları, ürünlerinizi/ hizmetlerinizi daha geniş bir kitleye ulaştırmanın ve satışlarınızı arttırmanın harika bir yoludur. Sosyal promosyonlarınız açık, ilgi çekici ve kolay anlaşılır olmalıdır. Hangi tekliflerin en fazla satışla sonuçlandığını görmek için promosyonları düzenli olarak test etmek gerekir. İçeriğinizin yüzde 80'i değer sağlamaya ve yüzde 20'si promosyona odaklanmış olarak, 80/20 kuralını uygulamak önemlidir. Bu şekilde, kitleniz satış odaklı içerikten etkilenmeyecek ve satın alamaya daha istekli olacaktır.

11. Sosyal Medyada Reklam Yayınlamak: Tüm önemli sosyal medya platformlarında satışlarınızı ve kitlenizin boyutunu büyütmeye yardımcı olacak sosyal reklamcılık özellikleri bulunmaktadır. Bir ürün veya hizmetinizi tanıtmak istiyorsanız, geçmişte gerçekleştirdiğiniz başarılı organik promosyonları tekrar gözden geçirmeli ve bu teklifin başarılı öğelerini ücretli promosyonunuzda nasıl yeniden kullanabileceğinizi düşünmelisiniz. Sosyal medya reklamlarınız, yeni ürün tanıtımları, e-kitap indirmeleri, web semineri / etkinlik tanıtımları, eşantiyonlardan oluşablir. Çoğu sosyal medya kanalında gerçekten para kazanmak için genellikle ücretli reklam kampanyalarını kullanmanız gerekir. Ücretli reklamlar, özellikle sosyal medya algoritmaları, mevcut takipçilerinizin kaçının organik (veya ücretsiz) promosyonlarınızı gördüğünü sınırladığından, daha geniş bir kitleye ulaşmanıza yardımcı olmaktadır.

Sosyal medya pazarlamasının etkinliği için içerik kalitesi, katılım ve diğer medya platformlarıyla entegrasyon 3 kritik faktördür. Müşterilerle güvene dayalı ve uzun vadeli ilişki kurulmalıdır. İçeriğin miktarı değil niteliği önemlidir. Etkili bir içerik, alçakgönüllülüğü, dürüstlüğü ve özü (kısa) yansıtmalıdır. Ayrıca, müşterilerin bilgi ve uzman görüşlerine olan ihtiyacını karşılamak için bilgilendirici olmalıdır. Sosyal medya pazarlaması, yalnızca şirketin web sitesine değil, aynı zamanda TV veya reklam panosu gibi tanıtım platformunun geri kalanına da entegre edilmelidir. İşletmeler, sosyal medya sitelerine katılımları teşvik ederken diğer medya platformlarını da dahil etmelidir (Pradiptarini, 2011:5-6). Diğer taraftan, Twitter'ın etkileşimi teşvik edecek şekilde tasarlanan doğası, hedef kitleyle hızlı bir şekilde iletişime geçmeye izin vermesi, Youtube kanallarının görüntülenme sayısı yüksekliği ve üye sayısı fazlalığı nedeniyle Twitter ve Youtube'a odaklanmak her sosyal medya pazarlama stratejisinde bir gerekliliktir (Mahesh ve Amulya, 2013:163-164). 


\section{SOSYAL MEDYA PAZARLAMASININ FAYDALARI VE ZORLUKLARI}

Web 2.0 ve 3G/4G teknolojilerindeki devam eden gelişmeler, işletmeler arası ilişkilerde bilgi kontrolünde önemli bir paradigma değişikliği oluşturmuştur. Müşteriler artık işletmelerin ve markayla ilgili pazarlama mesajlarının sadece pasif alıcıları değildir. Bunun yerine, işletmelerle görüşmeler başlatma, işletmelerle ilgili geri bildirimde bulunma, kendi aralarında içerik oluşturma ve paylaşma süreçlerinin aktif katılımcılarıdır (Pentina ve Koh, 2012:294). Çeşitli etkinliklerin paylaşılması ve bu etkinliklere katılması için çevrimiçi kanallar içeren sosyal medya, markaların cazip kitle segmentleriyle iletişim kurmasında giderek daha önemli bir yolu temsil etmektedir. Markalar sosyal medya pazarlamasını, bir pazarlama iletişimi kampanyasında entegre bir bileşen olarak, devam eden bir kurumsal iletişim kanalı olarak, dijital pazarlama için özel olarak tasarlanmış bir dizi mikro kampanya olarak kullanmaktadır. Ayrıca, sosyal ağlarda müşteri katılımı için markalı katılım fırsatları geliştirmek ve markalı içerik yayınlamak (içerik pazarlaması/sosyal yayıncılık), tüketici-marka ilişkilerini derinleştirmek, tüketici geri bildirimlerindeki ortak temaları keşfetmek için de sosyal medya pazarlamasına başvurulmaktadır (Ashley ve Tuten, 2015:15). Bütünsel ve başarılı bir sosyal medya kampanyası, farklı satış, pazarlama, müşteri hizmetleri, kurumsal iletişim ve diğer departmanların entegre faaliyetlerini gerektirir (Bae ve Zamrudi, 2018:857).

Bununla birlikte sosyal medya pazarlamasının diğer avantajlarını; marka bilinirliğini arttırmak, web sitesi trafiğini arttırmak, internet arama motoru sonuçlarının konumlarını geliştirmek, müşteri memnuniyetini arttırmak, marka sadakati geliştirmek, daha fazla çözüm ve ürün satmak, marka otoritesini arttırmak, maliyet avantajı sağlamak, gelişmiş pazar analizleri ve öngörüleri yapmak, alanında uzman ve düşünce lideri olmayı sağlamak, yeni ortaklıklar oluşturmak, genel tanıtım giderlerini azaltmak ve daha iyi araştırma projeleri sayesinde nitelikli getiriler üretmek şeklinde özetlemek de mümkündür https://www.bluefountainmedia.com/, E.T.: 17.02.2020; SI, 2016:3).

Çevrimiçi ortam sadece firsatlar değil, aynı zamanda sosyal medya pazarlama süreci için zorluklar da yaratmaktadır. Sosyal medya pazarlamasında dikkate alınması gereken beş temel dezavantaj vardır. Bu dezavantajlar şunlardır (Nadaraja ve Yazdanifard, 2013:5);

1. Yoğun Zaman: İşletmede çalışanlardan en az birinin, yorumları ve soruları cevaplamak, müşterinin değerli bulduğu ürün bilgilerini sağlamak ve her ağı izlemekten sorumlu olması gerekir. Bu da, sosyal medya pazarlamasının önemli bir zaman yatırımı gerektirmesine yol açar.

2. Ticari Marka ve Telif Hakkı Sorunları: Sosyal medya kullanırken, pazarlamacılar ticari markalarının ve telif haklarının kullanımını düzenli olarak izlemelidir. İşletmeler, medya kuruluşları aracılığıyla içerik sağlayanların fikri mülkiyetlerini kötüye kullanmamalarını sağlamak için, üçüncü taraf ve kendi sosyal medya platformlarını takip etmelidir. İşletmenin marka ve telif haklarının, işletme adı veya markalarıyla aynı veya büyük ölçüde benzer profil/ kullanıcı adları için sosyal medya sitelerinin kontrol edilmesi de dahil olmak üzere üçüncü taraf sitelerde kullanımını takip etmek için çeşitli internet izleme ve tarama hizmetleri bulunmaktadır.

3. Güven, Gizlilik ve Güvenlik Sorunlart: Güven, özellikle de işlemsel güvenlik ve gizlilik, sosyal medya pazarlamacılarına müşteri sadakati sağlamada önemli bir rol oynamaktadır. Araştırmalar, çevrimiçi kredi kartı sahtekârlığı korkusunun, müşterilerin daha fazla çevrimiçi satın alma işlemi yapmamasının başlıca nedenlerinden biri olduğunu göstermektedir. Kendi bloglarını veya diğer sosyal medya platformlarını yöneten işletmeler, işletmenin veri toplama, kullanma ve depolama uygulamalarını ve üçüncü tarafların gizlilik ve veri güvenliği ile ilgili sorumluluklarını açıklayan kapsamlı politikalar da sürdürmelidir. Twitter ve Facebook gibi sosyal medya şirketlerinin genel olarak tüketici verilerinin kullanımlarını ve sosyal medya platformunda kişisel verilerle ilgili üçüncü taraf davranışlarını yöneten kendi gizlilik politikaları vardır.

4. Kullanıcı Tarafindan Oluşturulan İçerik (UGC) : Kullanıı tarafindan oluşturulan içerik, , tüketicilerin gözünde nispeten yüksek bir güvenilirlik derecesine sahiptir. Kullanıcı tarafından oluşturulan içeriği bir pazarlama stratejisiyle bağlantılı olarak istemek, kampanyaya katılan kişi tarafından oluşturulan içerik için yasal sorumluluk alma riskiyle birlikte gelir. $\mathrm{Bu}$ yüzden pazarlamacılar, kullanıcı tarafindan oluşturulan içeriğin sosyal medya aracıllğıyla yayılmasını içeren pazarlama kampanyalarıyla ilişkili yasal riskleri en aza indirmek için önlemler almalıdır.

5. Olumsuz Geri Bildirimler: Sosyal medya, tüketicileri pazarlamacılara ve reklam verenlere dönüştürür ve bu da işletme için baskı yaratabilir. Çevrimiçi ürün seçimleri yapan müşteriler için değerli bir bilgi 
kaynağ 1 olarak hizmet veren, tüketici ürün incelemeleri, resimler ve etiketler, internet üzerinde hızla artmış ve Web 2.0 teknolojilerinin ortaya çıkmasının ardından elektronik ticaret üzerinde büyük bir etkiye sahip olmuştur. Sosyal ağların özellikle pazarlama kampanyalarına zarar veren bir yönü olumsuz tepkilerdir. Mutsuz müşteriler veya endüstri rakipleri, incitici veya rahatsız edici resimler, yayınlar veya videolar yayınlayabilir. Bu yüzden sosyal ağlar, zararlı yorumları/içerikleri hemen yanıtlayacak ve verimli bir şekilde yönetilmelidir.

\section{SONUÇ}

Son on yılda, sosyal medya platformları, günlük yaşamın mekaniğine derinlemesine nüfuz ederek, insanların resmi olmayan etkileşimlerini, kurumsal yapıları ve profesyonel rutinleri etkilemiştir. Sosyal medya, sosyal etkileşimin koşullarını ve kurallarını değiştirmiştir (Dijck ve Poell, 2013:2). Çevrimiçi sosyal ağlar, kişilerin bireylerin konumlarından bağımsız olarak başkalarıyla kolayca bağlantı kurmasını ve ilişkilerini sürdürmesini sağlar (Jurgens, 2013:273).

Sosyal medya, sadece günlük yaşamda değil, sosyal ilişkilerde de devrim yaratmıştır. Sosyal medya kullanımı, müşteri ilişkilerinin kurulması ve yönetimi için bir pazarlama aracı olarak giderek daha popüler hale gelmekte ve tüketicilerin alışveriş davranışlarını etkilemektedir. Tüketiciler sosyal medyayı sadece ürün/hizmetleri araştırmak için değil, aynı zamanda satın aldıklarını işletmeler ve bu işletmeler hakkında farklı öngörülere sahip olabilecek diğer tüketicilerle etkileşimde bulunmak için de giderek daha fazla kullanmaktadır. Geleneksel paradigmaya göre pazarlama, üreticinin üreten ve müşterinin alıcı olduğu tek yönlü etkileşim modelidir. Buna karşılık, sosyal medyanın pazarlamada kullanımı, gönderenin ve alıcının rollerinin karıştırıldığı çok yönlü bir etkileşim yaklaşımına dayanmaktadır. Farklı sosyal medya kullanımının birleşimi de pazarlama etkilerini güçlendirebilir (Lagrosen ve Grunden, 2014:255; Farook ve Abeysekara, 2016:115).

Günümüzde sosyal medya, birçok kurumun pazarlama stratejisinin ayrılmaz bir parçası haline gelmiştir. İşletmeleri, sosyal medyayı bir pazarlama aracı olarak kullanmaya iten nedenler arasında; ağızdan-ağıza pazarlamanın avantajlarından yararlanmak, marka sadakati geliştirmek, marka bilinirliğini attırmak, müşterilerle daha yakın ilişkiler kurmak ve medya/kamuoyunu işletme ile ilgili konular hakkında bilgilendirmek sayılabilir (Ananda vd., 2014:2; Ismail, 2017:137).

Sosyal medyanın başarısı için anahtar faktör iletişimdir. Bu sebeple işletmeler, müşterilerin soru ve sorunlarını yanıtlamak için zaman ve çaba harcamalıdır. Sosyal medya, pazarlama faaliyetleri için düşük maliyetli bir yöntemdir ve işletmeler tarafından minimum maliyetle ürün ve hizmetleri pazarlamanın en önemli yollarından biri olarak tercih edilmektedir. Ancak, sosyal medya sadece bir şirketin ürün ve hizmetlerini pazarlamak için değil, aynı zamanda müşterilerinin sorunlarını çözmek etkileşime girdiği ortamdır (Edosomwan vd., 2011:8-9). Sosyal medya kanalları aracılığıyla müşterileri etkilemek çok daha kolay hale gelmektedir. Bunun için etkili bir web sitesi ve içerikler oluşturmak, ziyaretçilerin beklediği içerikleri sağlamak, müşterilerle etkileşim kurmak, tutarlı bir iletişim tarzı belirlemek, promosyon stratejilerini kullanmak önemlidir (Bashar vd., 2012:98).

Sosyal medya sitelerinin kapsam ve işlevselliklerine göre değişen zengin ve çeşitli kullanım alanları bulunur. Örneğin, Facebook daha çok kişiye ulaşmak için uygundur. LinkedIn gibi siteler daha profesyonel odaklı ağlardır. MySpace, YouTube gibi medya paylaşım siteleri paylaşılan videolara ve fotoğraflara odaklanır. Twitter, kullanıcıların ne yaptığını, nerede olduklarını, nasıl hissettiklerini hakkında kısa durum güncellemeleri sunar (Kietzmann vd., 2011:242). Sosyal platformların her birinin kendi ekosistemi vardır (Manikandan ve Mohamed, 2020:398). Diğer taraftan, etkili bir sosyal medya stratejisi, pazarlama hedeflerini açıkça tanımlamalı, firsatları değerlendirmeli ve iletişim kurmak için uygun bir sosyal medya biçimi belirlemelidir. Sosyal medya kampanyalarının, yalnızca doğru sosyal medya platformunu seçildiğinde, doğru mesaj tasarlandığında ve bu mesajı yaymak için doğru kullanıcılarla etkileşime girildiğinde başarılı olduğu unutulmamalıdır (Kumar ve Mirchandani, 2012:55). 


\section{KAYNAKÇA}

AJINA, Ahmet S. (2019), "The Perceived Value of Social Media Marketing: An Empirical Study of Online Word of Mouth In Saudi Arabian Context", Entrepreneurship And Sustainability Issues, S.6(3), ss.1512-1527.

ALALWAN, Ali Abdallah, RANA, Nripendra P., DWIVEDI, Yogesh K. ve ALGHARABAT, Raed (2017), "Social Media in Marketing: A Review and Analysis of the Existing Literature", Telematics and Informatics, S.34(7), ss.1-38.

ANANDA, Artha Sejati, HERNANDEZ-GARCIA, Ángel ve LAMBERTI, Lucio (2014), "RENL: $A$ Framework for Social Media Marketing Strategy", Research Challenges in Contemporary Management Engineering, 1st Annual EDIM PhD Conference, ss.1-10.

ANSARI, Sinoka, ANASARI, Ghishwa, GHORI, Muhammad Umar ve KAZI, Abdul Ghafoor (2019), "Impact of Brand Awareness and Social Media Content Marketing on Consumer Purchase Decision", Journal of Public Value and Administration Insights, JPVAI, S.2(2), ss.5-10.

ASHLEY, Christy ve TUTEN, Tracy (2015), “Creative Strategies in Social Media Marketing: An Exploratory Study of Branded Social Content and Consumer Engagement", Psychology and Marketing, S.32(1), ss.15-27.

BAE, Il-Hyun ve ZAMRUDI, Muhammad Faisal Yul (2018), "Challenge Of Social Media Marketing \& Effective Strategies to Engage More Custemers: Selected Retalier Case Study", International Journal of Business and Society, S.19(3), ss.851-869.

BASHAR, Abu, AHMAD, Irshad ve WASIQ, Mohammad (2012), "Effectiveness of Social Media As A Marketing Tool: An Empirical Study", International Journal of Marketing, Financial Services \& Management Research, S.1(11), ss.88-99.

BATEMAN, Patrick J., KEILlOR, Bruce D., PIKE, Jacqueline C. ve BUTLER, Brian S. (2019), "Social Marketing: Lessons For Managing Social Media Initiatives", Innovative Marketing, S.7(3), ss.100-108.

BELFIORE, Patrizia , ROSA, Roberta ve TAFURI, Domenico (2019), "The Management of Social Media For Sport Promotion: A Survey”, Sport Science, S.12(1), ss.45-48.

BRENNAN, Ross ve CROFT, Robin (2012), "The Use of Social Media in B2B Marketing and Branding: An Exploratory Study”, Journal of Customer Behaviour, S.11(2), ss.101-115.

CHEN, Shih Chih ve LIN, Chieh-Peng (2019), "Understanding The Effect of Social Media Marketing Activities: The Mediation of Social Identification, Perceived Value and Satisfaction”, Technological Forecasting \& Social Change, S.140, ss.22-32.

CHEUNG, Man Lai, PIRES, Guilherme D., ROSENBERGER III, Philip J. ve DE OLIVEIRA, Mauro Jose (2019), "Consumers Online Brand Related Activities on WeChat: The Role of Social Media Marketing Efforts", CLAV, ss.1-16.

CHIANG, I-Ping, WONG, Ray ve HUANG, Chih-Hui (2019), "Exploring The Benefits of Social Media Marketing For Brands and Communities", International Journal of Electronic Commerce Studies, S.10(2), ss.113-140.

COELLA, Giuseppe, AMATULLI, Cesare ve MARTINEZ-RUIZ, Maria Pilar (2019), "Social Media Marketing and Luxury Consumption: A Literature Review", International Journal of Marketing Studies, S.11(4), ss.30-52.

CONSTANTINIDES, Efthymios (2014), "Foundations of Social Media Marketing”, Procedia - Social and Behavioral Sciences, S.148, ss.40-57.

COX, Daniel D. ve McLEOD, Scott (2014), "Social Media Marketing and Communications Strategies for School Superintendents", Journal of Educational Administration, S.52(6), ss.850-868.

DIJK, Jose Van ve POELL, Thomas (2013), "Understanding Social Media Logic", Media and Communication, S.1(1), ss.2-14. 
DWIVED, Yogesh K., KAPOOR, Kawaljeet Kaur ve CHEN, Hsin (2015), "Social Media Marketing and Advertising”, The Marketing Review, S.15(3), ss.289-309.

EDOSOMWAN, Simeon, PRAKASAN, Sitalaskshmi Kalangot, KOUAME, Doriane, WATSON, Jonelle ve SEYMOUR, Tom (2011), "The History of Social Media and its Impact on Business", The Journal of Applied Management and Entrepreneurship, S.16(3), ss.1-13.

FAROOK, F. Safwa ve ABEYSEKARA, Nalin (2016), "Influence of Social Media Marketing on Customer Engagement", International Journal of Business and Management Invention, S.5(12), ss.115-125.

FELIX, Reto, RAUSCHNABEL, Philipp A. ve HINSCH, Chris (2017), "Elements of Strategic Social Media Marketing: A Holistic Framework”, Journal Of Business Research, S.70, ss.118-126.

GEORGE, Ellen Maureen ve LEWENSTEIN, Bruce V. (2019), “Communicating Fisheries Science Using Social Media", Cisco Coregonus Artedi Restoration in Lake Ontario: Ecology, Genetics and Science Communication, ss.99-116.

GLENDAH , Sindani Tsimbiri, ALALAl , Ondiek B. ve DISHON, Wanjere (2019), "Social Media Marketing and Brand Loyalty At Sararicom Company, Kenya", European Journal of Business and Strategic Management, S.4(5), ss.49-64.

GRETZEL, Ulrike (2019), "The Role of Social Media in Creating and Addressing Overtourism: Issues, Realities and Solutions", De Gruyter, Boston, ss.62-75.

HARRIS, Albert L. ve REA, Alan (2019), “Web 2.0 and Virtual World Technologies: A Growing Impact on IS Education”, Journal of Information Systems Education, S.20(2), ss.137-144.

IRSHAD, Madeeha ve AHMAD, Muhammad Shakil (2019), "Investigating the Determinants of Consumers' Attitude Towards Social Media Marketing: Moderating Role of Gender", Online Journal of Communication and Media Technologies, S.9(4), ss.1-15.

ISMAIL, Ahmed Rageh (2017), "The Influence of Perceived Social Media Marketing Activities on Brand Loyalty: The Mediation Effect of Brand and Value Consciousness", Asia Pacific Journal of Marketing and Logistics, S.29(1), ss.129-144.

JURGENS, David (2013), “That's What Friends Are For: Inferring Location in Online Social Media Platforms Based on Social Relationships", Proceedings of the Seventh International AAAI Conference on Weblogs and Social Media, ss.273-282.

KAPLAN, Andreas M. ve HAENLEIN, Michael (2010), "Users of The World, Unite! The Challenges and Opportunities of Social Media”, Business Horizons, S.53, ss.59-68.

KIETZMANN, Jan H., HERMKENS, Kristopher, McCARTHY, Ian P. ve SILVESTRE, Bruno S. (2011), "Social Media? Get serious! Understanding the Functional Building Blocks of Social Media", Business Horizons, S.54(3), ss.241-251.

KIM, Angella J. ve KO, Eunju (2012), "Do Social Media Marketing Activities Enhance Customer Equity? An Empirical Study of Luxury Fashion Brand”, Journal of Business Research, S.65, ss.1480-1486.

KUMAR, V. ve MIRCHANDANI, Rohan (2012), "Increasing the ROI of Social Media Marketing", MIT Sloan Management Review, S.54(1), ss.55-61.

LAGROSEN, Stefan Olof ve GRUNDEN, Kerstin (2014), "Social Media Marketing in The Wellness Industry”, The TQM Journal, S.26(3), ss.253-260.

LEUNG, Xi Y., BAI, Billy ve STAHURA, Kurt A. (2015), "The Marketing Effectiveness of Social Media in The Hotel Industry: A Comparison of Facebook and Twitter", Journal of Hospitality \& Tourism Research, S.39(2), ss.147-169.

MAHESH , L. ve AMULYA, M. (2013), "Social Media Marketing: An Important Phase in Modern Business Management", CLEAR International Journal of Research in Commerce \& Management, S.4(3), ss.162-164.

MANIKANDAN, M. ve MOHAMED, K.Naina (2020), "Social Marketing Media”, Studies in Indian Place Names, S.40(12), ss.393-398. 
MAZUREK, Grzegorz, KORZYNSKI, Paweł ve GORSKA, Anna (2019), "Social Media in The Marketing of Higher Education Institutions in Poland: Preliminary Empirical Studies", Entrepreneurial Business and Economics Review, S.7(1), ss.117-133.

McLOUGLIN, Catherine E. ve ALAM, Sultana Lubna (2019), “A Case Study of Instructor Scaffolding Using Web 2.0 Tools To Teach Social Informatics", Journal of Information Systems Education, S.25(2), ss.125-136.

NADARAJA, Rubathee ve YAZDANIAFARD, Rashad (2013), "Social Media Marketing: Advantages and Disadvantages", Center of Southern New Hempshire University, ss.1-10.

ORENGA-ROGLA, Sergio ve CHALMETA, Ricardo (2019), "Methodology For The Implementation of Knowledge Management Systems 2.0: A Case Study in An Oil and Gas Company", Business \& Information Systems Engineering, S.61(2), ss.195-213.

PAN, Yating, TORRES, Ivonne M. ve ZUNIGA, Miguel Angel (2019), "Social Media Communications and Marketing Strategy: A Taxonomical Review of Potential Explanatory Approaches", Journal of Internet Commerce, S.18(1), ss.73-90.

PAQUETTE, Holly (2013), "Social Media as a Marketing Tool: A Literature Review", Major Papers by Master of Science Students, https://digitalcommons.uri.edu/tmd_major_papers/2, ss.1-27.

PASWAN, Ashwani (2018), "Social Media Marketing Strategies", DAWN: Journal for Contemporary Research in Management, S.5(1), ss.8-11.

PENTINA, Iryna ve KOH, Anthony C. (2012), "Exploring Social Media Marketing Strategies in SMEs", International Journal of Internet Marketing and Advertising, S.7(4), ss.292-310.

PINHEIRO, Petrilson (2020), “Text Revision Practices in an E-Learning Environment: Fostering The Learning By Design Perspective", Innovation in Language Learning and Teaching, S.14(1), ss.37-50.

PODDAR, Natika ve AGARWAL, Dipti (2019), "A Comparative Study of Application Effectiveness Between Digital and Social Media Marketing for Sustainability of Start-Ups", International Journal of Business Insights \& Transformation, S.12(2), ss.50-54.

PRADIPTARINI, Charity (2011), "Social Media Marketing: Measuring Its Effectiveness and Identifying the Target Market”, UW-L Journal of Undergraduate Research, S.14, ss.1-11.

QUY, Nguyen Hong, HONG, Ngoc T. L., HIEU, Thao N. ve LE, Tri D. (2019), "Social Media Marketing: Creative Strategies, Contents and Customer Engagement", E-Proceedings of 2nd d Connect-Us Conference, $\mathrm{CuC} 2019$, ss.61-65.

RAUT, Savita M. ve KULKARNI, S. (2020). “A Study on Use of Social Media Marketing Strategies”, Our Heritage, S.68(Special Issue 25), ss.28-34.

SHAIFUL, Puteri Sarah Hanim Mohamad, MOHAMED, Shazleen ve SAAHAR, Suhaimee (2019), "Perceived Effect of Social Media Marketing on Malaysian Film Audience", Proceedings of the 5th World Conference on Media and Mass Communication, S.5(1), ss.154-160.

SI, Sajid (2016), “Social Media and Its Role in Marketing”, Business and Economics Journal, S.7(1), ss.1-5.

SOEGOTO, E. ve UTOMO, A. (2019), "Marketing Strategy Through Social Media”, IOP Conference Series: Materials Science and Engineering, S.662(3), IOP Publishing, ss.1-7.

THEOCHARIDIS, Anastasios Ioannis, KARAVASILIS, George, VRANA, Vasiliki, KEHRIS, Evangelos ve ANTONIADIS, Konstantinos (2019), "What is Affecting Customers Intention to Perform Social Media Marketing Activities in the Hotel Industry?", Smart Tourism as a Driver for Culture and Sustainability, Springer, Cham, ss.375-391.

TIAGO, Maria Teresa Pinheiro Melo Borges ve VERISSIMO, Jose Manuel Cristovao (2014), "Digital Marketing and Social Media: Why Bother?", Business Horizons, S.57, ss.703-708.

TSIMONIS, Georgios ve DIMITRIADIS, Sergios (2014), "Brand Strategies in Social Media", Marketing Intelligence \& Planning, S.32(3), ss.328-344.

TSIMONIS, Georgios ve DIMITRIADIS, Sergios (2019), "The Conceptualisation and Measurement of Perceived Value in Social Media: The Case of Facebook Brand Pages", E-Article, ss.1-12, 
https://www.dora.dmu.ac.uk/xmlui/bitstream/handle/2086/17589/AMA_2019.pdf?sequence=1\&isAllowe $\mathrm{d}=\mathrm{y}$ (Erişim Tarihi: 22.02.2020).

VINEREAN, Simona, CETINA, Iuliana, DUMITRESCU, Luigi ve TICHINDELEAN, Mihai (2013), "The Effects of Social Media Marketing on Online Consumer Behavior”, International Journal of Business and Management, S.8(14), ss.66-79.

WALASKI, Pamela (2013), "Social Media - Powerful Tools for SH\&E Professionals", Professional Safety, S.58(04), ss.40-49.

YANG, Xin ve WANG, Dan (2015), "The Exploration of Social Media Marketing Strategies of Destination Marketing Organizations in China", Journal of China Tourism Research, S.11(2), ss.166-185.

ZIYADDIN, Sayabek, DOSZHAN, Raigul, BORODIN, Alex, OMAROVA, Aizhan ve ILYAS, Aigerim (2019), "The Role of Social Media Marketing in Consumer Behaviour", E3S Web of Conferences, 135, EDP Sciences, ITESE-2019, ss.1-9.

https://digitalmarketinginstitute.com/blog/which-social-media-platforms-should-you-use-for-your-business,

(2020). "Which Social Media Platforms Should You Use For Your Business?”, (Erişim Tarihi: 12.03.2020).

https://fitsmallbusiness.com/social-media-marketing-strategy/, (2018), "11-Step Social Media Marketing Strategy That Works + Free Template", M.Paquet, (Erişim Tarihi: 26.02.2020).

https://influencermarketinghub.com/social-media-sites/, (2020), "50+ Social Media Sites You Need to Know in 2020", (Erişim Tarihi: 14.03.2020).

https://wearesocial.com/blog/2020/01/digital-2020-3-8-billion-people-use-social-media, (2020), "Digital 2020: 3.8 Billion People Use Social Media”, S. Kelp, (Erişim Tarihi: 22.02.2020).

https://www.bluefountainmedia.com/blog/advantages-of-social-media-marketing, (2020), "10 Advantages of Social Media Marketing for Your Business", (Erişim Tarihi: 17.02.2020).

https://www.searchenginejournal.com/social-media/biggest-social-media-sites/\#close, (2020), "The 7 Biggest Social Media Sites in 2020”, K. Kellogg, (Erişim Tarihi: 05.03.2020).

https://www.statista.com/topics/1164/social-networks, (2019), "Social media - Statistics \& Facts", J.Clement, (Erişim Tarihi: 25.02.2020).

https://www.statista.com/topics/1267/pinterest, (2020), "Pinterest - Statistics \& Facts", J.Clement, (Erişim Tarihi: 04.03.2020).

https://www.statista.com/topics/1882/instagram, (2019), “Instagram - Statistics \& Facts”, J.Clement, (Erişim Tarihi: 12.03.2020).

https://www.statista.com/topics/2018/whatsapp/, (2019), “WhatsApp - Statistics \& Facts”, J.Clement, (Erişim Tarihi: 16.02.2020).

https://www.statista.com/topics/2019/youtube, (2019), "YouTube - Statistics \& Facts", J.Clement, (Erişim Tarihi: 03.03.2020).

https://www.statista.com/topics/2882/snapchat, (2020), "Snapchat - Statistics \& Facts", J.Clement, (Erişim Tarihi: 05.03.2020).

https://www.statista.com/topics/737/twitter, (2020), “Twitter - Statistics \& Facts”, J.Clement, (Erişim Tarihi: 06.03.2020).

https://www.statista.com/topics/751/facebook, (2020), "Facebook - Statistics \& Facts" , J.Clement, (Erişim Tarihi: 16.03.2020).

https://www.statista.com/topics/951/linkedin, (2019), "LinkedIn - Statistics \& Facts", J.Clement, (Erişim Tarihi: 25.02.2020). 